\title{
Hand hygiene in high-complexity sectors as an integrating element in the combat of Sars-CoV-2
}

\author{
Higiene das mãos em setores de alta complexidade como elemento integrador no combate do Sars-CoV-2
}

Higiene de las manos en sectores de alta complejidad como elemento integrador en el combate del Sras-CoV-2

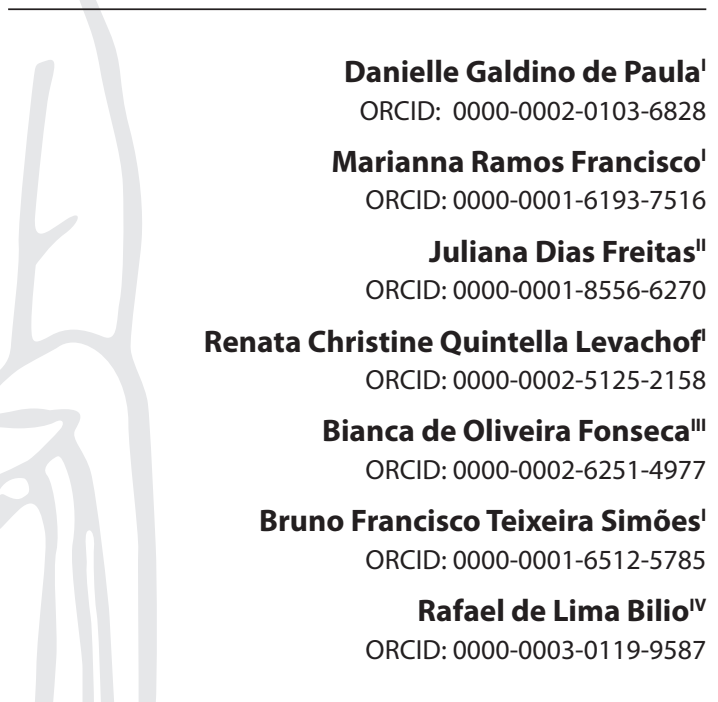

'Universidade Federal do Estado do Rio de Janeiro. Rio de Janeiro, Rio de Janeiro, Brazil.

"University Medical Center Schleswig-Holstein. Kiel, Schleswig-Holstein, Germany.

"'Hospital Federal da Lagoa. Rio de Janeiro, Rio de Janeiro, Brazil. "Fundação Oswaldo Cruz. Rio de Janeiro, Rio de Janeiro, Brazil.

How to cite this article: De Paula DG, Francisco MR, Freitas JD, Levachof RCQ, Fonseca BO, Simões BFT, et al. Hand hygiene in highcomplexity sectors as an integrating element in the combat of Sars-CoV-2. Rev Bras Enferm. 2020;73(Suppl 2):e20200316. doi: http://dx.doi.org/10.1590/0034-7167-2020-0316

Corresponding author:

Danielle Galdino de Paula E-mail: danielle.paula@unirio.br

EDITOR IN CHIEF: Dulce Aparecida Barbosa ASSOCIATE EDITOR: Antonio José de Almeida Filho

\section{ABSTRACT}

Objective: to perform a situational diagnosis of the behavior of health professionals concerning hand hygiene practices in highly-complex sectors. Methods: this quantitative and retrospective study was based on reports (2016 and 2017) of Adult and Pediatric ICUs of a Federal hospital in Rio de Janeiro. Results: one thousand two hundred fifty-eight opportunities for hand hygiene were analysed. The chance of professionals sanitizing hands in Pediatric ICUs is $41.61 \%$ higher than in Adult ICUs. Concerning proper hand hygiene, the medical team had a $39.44 \%$ lower chance than the nursing team. Others had a $30.62 \%$ lower chance when compared to the nursing team. The moment "after contact with the patient" presented 4.5275 times the chance in relation "before contact with the patient". Conclusion: in front of hand hygiene recommendations to control COVID-19, diagnostic assessment and previous analysis of the behavior of professionals proved to be positive.

Descriptors: SARS Virus; Hand Hygiene; Cross Infection; Intensive Care Units; Nursing.

\section{RESUMO}

Objetivo: realizar um diagnóstico situacional do comportamento de profissionais de saúde quanto às práticas de higienização das mãos em setores de alta complexidade. Métodos: estudo quantitativo, retrospectivo, baseado em relatórios (anos de 2016 e 2017) dos setores CTI Adulto e Pediátrico de um hospital Federal do Rio de Janeiro. Resultados: analisaram-se 1.258 oportunidades para higiene das mãos. A chance de um profissional higienizar as mãos no CTI Pediátrico é $41,61 \%$ maior que no CTI Adulto. Quanto higienizar as mãos adequadamente, a equipe médica obteve chance $39,44 \%$ menor que a equipe de enfermagem e outros tiveram chance $30,62 \%$ menor quando comparada à equipe da enfermagem. O momento "após o contato com o paciente" apresentou 4,5275 vezes a chance em relação a "antes do contato com o paciente". Conclusão: frente à recomendação da higiene das mãos no controle da COVID-19, avaliação diagnóstica e análise prévia do comportamento dos profissionais demonstrou ser positiva.

Descritores: Vírus da SARS; Higiene das Mãos; Infecção Hospitalar; Unidades de Terapia Intensiva; Enfermagem.

\section{RESUMEN}

Objetivo: realizar un diagnóstico situacional del comportamiento de los profesionales de la salud con respecto a las prácticas de higiene de manos en sectores altamente complejos. Métodos: estudio cuantitativo, retrospectivo, basado en informes (años 2016 y 2017) de los sectores de UCI Adultos y Pediátricos de un hospital federal en Rio de Janeiro. Resultados: se analizaron 1.258 oportunidades de higiene de manos. La posibilidad de un lavado de manos profesional en la UCI Pediátrica es $41.61 \%$ mayor que en la UCl Adultos. Con respecto a la higiene de las manos, el equipo médico tuvo una probabilidad $39.44 \%$ menor que el equipo de enfermería y otros tuvieron una probabilidad $30.62 \%$ menor en comparación con el equipo de enfermería. El momento "después del contacto con el paciente" fue 4.5275 veces mayor que "antes del contacto con el paciente". Conclusión: contra la recomendación de higiene de manos en el control de COVID-19, la evaluación diagnóstica y el análisis previo del comportamiento de los profesionales resultaron ser positivos.

Descriptores: Virus del SRAS; Higiene de las Manos; Infección Hospitalaria; Unidades de Cuidados Intensivos; Enfermería.

Submission: 04-20-2020 Approval: 04-21-2020 


\section{INTRODUCTION}

The emerging COVID-19 disease caused by the Sars-CoV-2 virus was first identified in Wuhan, China, in December 2019. The virus has caused a pandemic and is spreading rapidly and, in many countries, increased demand for health services by people with disease-related complications is reported, which may overwhelm/ collapse health systems and high demand for hospitalization in high-complexity sectors ${ }^{(1)}$.

Studies have shown that analysis of surfaces of objects present in wards and toilets of patients in isolation with COVID-19 showed positive results of the pathogen on environmental surfaces. Among the surfaces analysed with positive findings were table, hospital bed grid, closet, chair, light switches, doors (inhaled door handle), windows, and toilet surfaces ${ }^{(2-3)}$.

The World Health Organization (WHO), Pan American Health Organization (PAHO) and government health agencies have been considering hand hygiene $(\mathrm{HH})$ as one of the preventive integrative actions. This is because there is sufficient scientific evidence supported that, if properly implemented, $\mathrm{HH}$ can significantly reduce the risk of transmission of the virus Sars-CoV-2 in society and health services ${ }^{(4-5)}$.

In this context, WHO develops actions and policies related to the incentive of $\mathrm{HH}$, where this practice was already analysed in health environments, as one of the key elements in the control of infection in a hospital environment ${ }^{(6)}$.

Although $\mathrm{HH}$ is a simple, fast and economically viable action, non-compliance with this technique by health professionals is still considered a challenge in infection control in health services ${ }^{(7)}$.

\section{OBJECTIVE}

To perform a situational diagnosis of the behavior of health professionals concerning $\mathrm{HH}$ practices in highly-complex sectors.

\section{METHODS}

\section{Ethical aspects}

REC approved the study and CAAE (Certificado de Apresentação para Apreciação Ética - Certificate of Presentation for Ethical Consideration). The study is in compliance with Resolution 466/12 of the Brazilian National Health Council (Conselho Nacional de Saúde) on research involving human beings.

\section{Study design, period, and place}

This cross-sectional, retrospective, and quantitative study was developed from reports referring to the years 2016 and 2017, obtained through studies conducted by the Hospital Infection Control Service (HICS) of a Federal hospital based in the city of Rio de Janeiro.

The Strengthening the Reporting of Observational Studies in Epidemiology (STROBE) initiative was used to assist in the methodological conduction of the study.

\section{Population and sample; inclusion and exclusion criteria}

The bank used for the analyses was constructed from observations made and based on the Guide to the Implementation of the
WHO Multimodal Hand Hygiene Improvement Strategy ${ }^{(8)}$ According to the $\mathrm{WHO}$, this is an assisting guide on $\mathrm{HH}$ in health services to improve practice and reduce healthcare-associated infections (HAls). The observations contained in the reports were made in the period of August, September and October 2016 and in June, July, August and September 2017. This period was chosen, as it was months subsequent to the educational strategies of $\mathrm{HH}$ held annually at the institution. The observations contained in the report were made during the morning and afternoon, from Monday to Friday, except holidays.

As an inclusion criterion, it was decided to analyse only the data referring to the sectors of the Intensive Care Center (ICU) of Adult and Pediatric units, as they are sectors previously described in literature with a high incidence of multi-resistant microorganisms. Observations related to companions and visitors were not reported, therefore, they were excluded from the analysis.

The study population was all health professionals who worked in the high complexity sector. Subsequently, this population was categorized as assistants, nursing technicians and nurses, as a nursing team; doctors, such as medical staff. Physiotherapists, speech therapists, nutritionists, nutrition and laboratory technicians and general service assistants were categorized as "others".

\section{Study protocol}

We tried to categorize the teams in order to have a larger sample size and obtain more statistically significant results for this study. The choice by all professionals is due to the recommendation contained in the Guide to the Implementation of the WHO Multimodal Hand Hygiene Improvement Strategy, since it is based on the principle that all professionals should have a safe practice, the realization of the five moments of $\mathrm{HH}$ according to the recommendations of the ANVISA/WHO protocol(8).

In data collection, the convenience sampling technique was used, a non-probabilistic technique, where sample became composed of the opportunities that arose in the analysed period. The data from reports were compiled into spreadsheets of the Microsoft Excel 2013 Program and analysed using R 3.4.2 ${ }^{\circ}$.

The actions (opportunities) were presented as $\mathrm{HH}$, performing it incorrectly or not performing $\mathrm{HH}$. These actions, when performed (correctly or inappropriately), were associated with the five moments of $\mathrm{HH}$ as before contact with the patient, before the aseptic procedure, after the risk of exposure to body fluids, after contact with the patient and with surfaces close to the patient ${ }^{(8)}$.

\section{Analysis of results, and statistics}

We opted for multiple correspondence analysis (MCA), because it is a multivariate statistical analysis technique that allows the graphic visualization of the most important associations of a large set of variables among themselves. With MCA, it is possible to assess which actions, based on the five moments of $\mathrm{HH}$ and alcoholic solution or water and soap use, were more associated with professional categories. Thus, relationships of proximity and opposition of behavior between professional categories and the actions observed ${ }^{(9)}$ are defined.

We chose the chi-square test to verify statistical significance in the associations between the variables analysed in this study. 


\section{RESULTS}

Based on the reports, 1,258 opportunities for $\mathrm{HH}$ were observed. In both years, 2016 and 2017, the nursing team totaled the largest number of opportunities observed. This result is related to the work activity developed by the nursing team, since intensive care is characterized by direct care, implying the performance of several procedures in the patient.

For the reader's understanding, the sectors (Adult ICU and Pediatric ICU) were grouped by year and association (times of hygiene and solutions used), being carried out based on the professional category of the population studied.

Concerning the year 2016, 785 opportunities for $\mathrm{HH}$ were observed. Of this total, 437 opportunities were related to Adult ICUs, with 284 opportunities for $\mathrm{HH}$ from the nursing team, 108 opportunities for $\mathrm{HH}$ from the medical team and 45 opportunities for $\mathrm{HH}$ from the "others" category. In the Pediatric ICU, there were 348 opportunities, of which 183 were opportunities for $\mathrm{HH}$ from the nursing team, 86 were opportunities for $\mathrm{HH}$ from the medical team and 79 were opportunities for $\mathrm{HH}$ in the "others" category.

According to Figure 1, we have three ellipses that refer to each professional category analysed in the scenarios contained in the reports (Adult ICU and Pediatric ICU). There was statistical significance between $\mathrm{HH}$ and solution used (chi-square $=18.192$ and $p$ value $<0.01$ ) and statistical significance of the professional team in relation to the moments for $\mathrm{HH}$ (chi-square $=52.712$ and $p$ value $<0.001$ ). In both sectors, the nursing team is associated with "alcoholic solution" use. In relation to moments of $\mathrm{HH}$, this professional category is associated (in both sectors) with "after contact with neighbors" and "after contact with the patient". In both sectors, the medical team is associated with "alcoholic solution" and "not performing hygiene". As for opportunities, the medical team is associated with "after proximity", "after contact with the patient" and "before contact with the patient". The category "others" is associated with "water and soap" use or "not performed" related to the moments of $\mathrm{HH}$. The actions were more associated with Pediatric ICUs, being "after risk of exposure" and "before contact with the patient".

In the reports for the year 2017,473 opportunities for $\mathrm{HH}$ were observed. Of this total, 194 observations of $\mathrm{HH}$ opportunity were related to Adult ICUs, with 118 opportunities referring to the nursing team, 32 opportunities related to the medical team and 44 opportunities practices, 2017 related to the "other" category. In Pediatric ICUs, we had a total of 156 opportunities, 83 of which were related to the nursing team, 49 were related to the medical team and 24 were related to the "other" category.

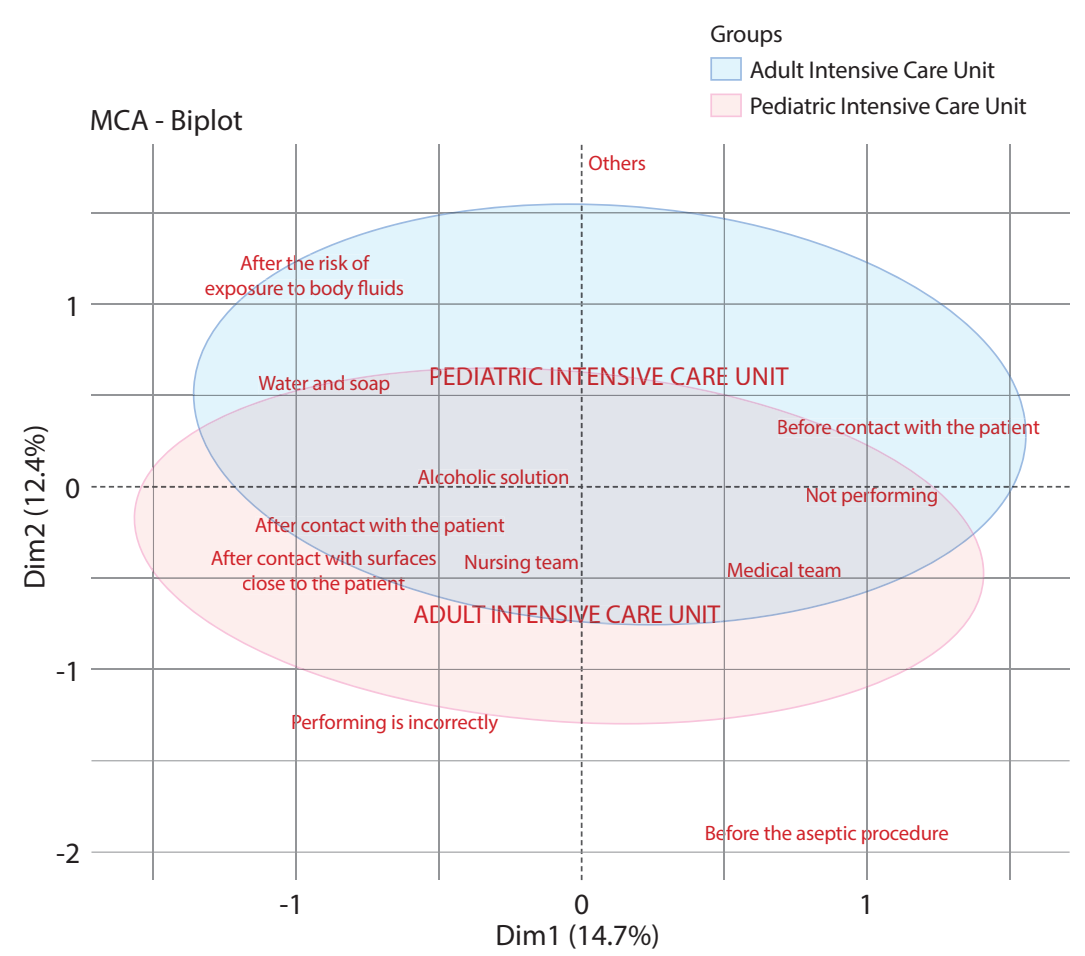

Figure 1 - Diagnosis situational behavior of health professionals and their hand hygiene practices, 2016

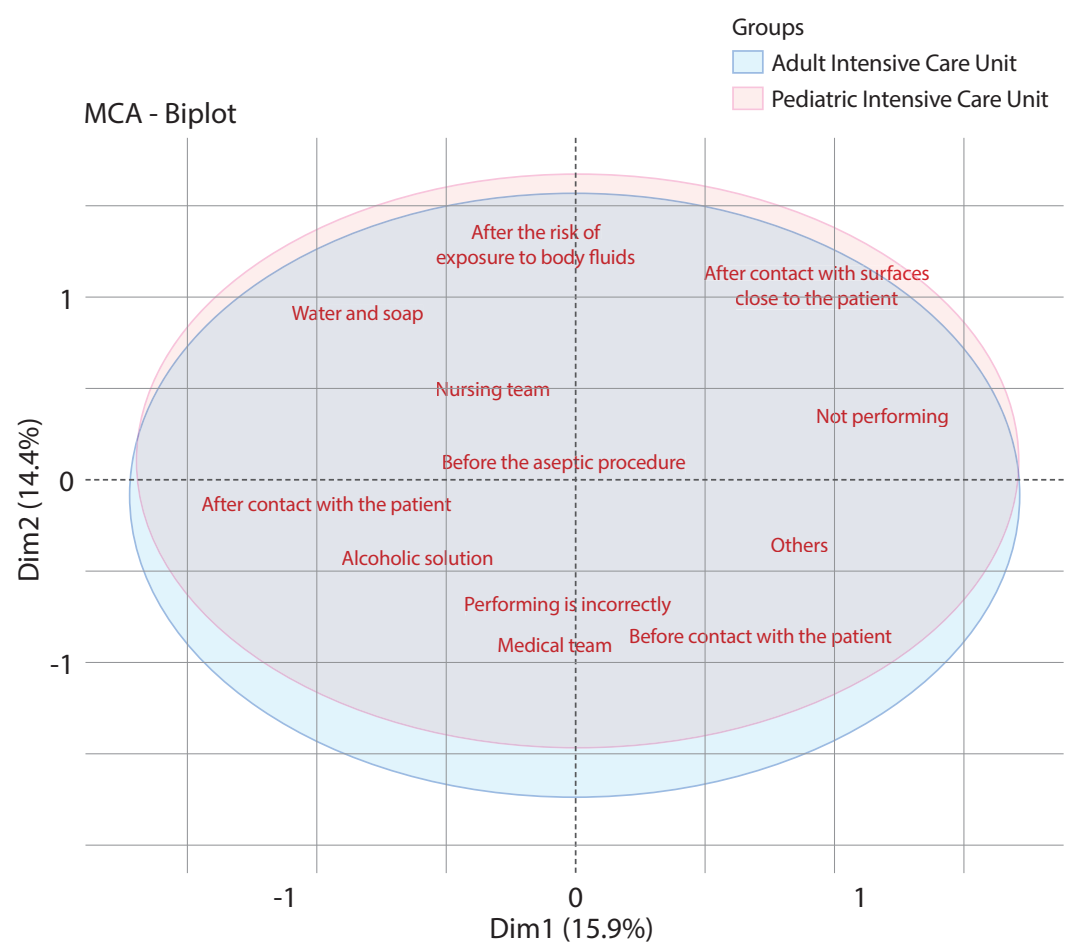

Figure 2 - Diagnosis situational behavior of health professionals and their hand hygiene 
According to Figure 2, again, the ellipses refer to the professional categories analysed in the same scenarios as the reports studied in 2017 (Adult ICU and Pediatric ICU). There was statistical significance between the categories and the type of hygiene (chi-square $=18.594$ and $\mathrm{p}$ value $<0.01$ ) and statistical significance between the moments for $\mathrm{HH}$ (chi-square $=28.159$ and $p$ value $<0.001$ ) and the type of professional team evaluated. It was found that the behavior of the groups in both sectors was similar. The nursing team is associated with "soap and water" and "alcoholic solution" use. In relation to the moments of $\mathrm{HH}$, this category is associated with "before the aseptic procedure", "after contact with the patient", "after contact with neighbors", "after risk of exposure" and "after proximity". The medical team was associated with "inadequate hygiene" and "alcoholic solution" use. In relation to moments of $\mathrm{HH}$, this category is associated with "before contact with the patient", "before the aseptic procedure" and "after contact with the patient". The category "others" was associated with "inadequate hygiene", and when performing $\mathrm{HH}$, it uses "alcoholic solution", and the action is associated with "before contact with the patient" and "before the aseptic procedure".

Table 1 presents the odds ratios (OR) of an adjusted logistic regression, with and soap and/or alcoholic solution use as a dependent variable as a dependent variable in the act of hand hygiene related to the sector, by category and by moment. Figure 3 shows the main effects of the variables on the dependent variable. In relation to the sector, in the analysed periods (2016 and 2017), the Odds Ratio of health professionals to perform $\mathrm{HH}$ in Pediatric ICUs was $\mathrm{OR}=1.42$, i.e., $42 \%$ higher than in Adult ICUs ( $p$ value $<0.01$ ).

Table 1 - Odds Ratio of the variables team, time of hygiene and sector, considering water and soap and/or alcoholic solution use as a dependent variable (2016 and 2017)

\begin{tabular}{|c|c|c|c|}
\hline Variable & Category & $\mathbf{n}^{* * *}$ & $(95 \% \mathrm{Cl}) \mathrm{OR}$ \\
\hline \multirow[t]{3}{*}{ Team } & Nursing & 733 & 1 \\
\hline & Medical & 306 & $0.6056^{* *}(0.4828 ; 0.8704)$ \\
\hline & Others & 219 & $0.6938^{*}(0.5012 ; 0.9603)$ \\
\hline \multirow[t]{5}{*}{$\begin{array}{l}\text { Moment of } \\
\text { hygiene }\end{array}$} & $\begin{array}{l}\text { Before contact with } \\
\text { the patient }\end{array}$ & 360 & 1 \\
\hline & $\begin{array}{l}\text { Before the aseptic } \\
\text { procedure }\end{array}$ & 44 & $1.4439(0.7583 ; 2.7256)$ \\
\hline & $\begin{array}{l}\text { After contact with the } \\
\text { patient }\end{array}$ & 593 & $4.5275^{* *}(3.4141 ; 6.0313)$ \\
\hline & $\begin{array}{l}\text { After contact with } \\
\text { neighbors }\end{array}$ & 186 & $1.3216(0.9131 ; 1.9123)$ \\
\hline & After risk of exposure & 75 & $2.2674 *(1.3591 ; 3.8226)$ \\
\hline \multirow[t]{2}{*}{ Sector } & Adult ICU & 689 & 1 \\
\hline & Pediatric ICU & 569 & $1.4161 *(1.1120 ; 1.8068)$ \\
\hline
\end{tabular}

Note: ${ }^{*} p$ value $<0.01 ;{ }^{* *} p$ value $<0.001 ;{ }^{* * *}$ number of observation opportunities.

As for the category of health professionals, the "nursing team" was used as a reference for analysis. When this category is compared to the "medical team", OR $=0.6056$ and $p$ value $<0.001$ are observed, that is, the "medical team" has a 39.44\% lower chance of performing the $\mathrm{HH}$ procedure with the inputs appropriate. The "others" team had OR $=0.6938$ and $p$ value $<0.01$, i.e., with a $30.62 \%$ lower chance of performing hygiene properly when compared to the "nursing team".

Regarding the moments of $\mathrm{HH}$, taking as a reference the time of cleaning "before contact with the patient", one of the most relevant ORs found was related to the time of cleaning "after contact with the patient", with $\mathrm{OR}=4.5275$ and $\mathrm{p}$ value $<0.001$, i.e., 4.5275 times the chance in relation to the procedure before contact with the patient.
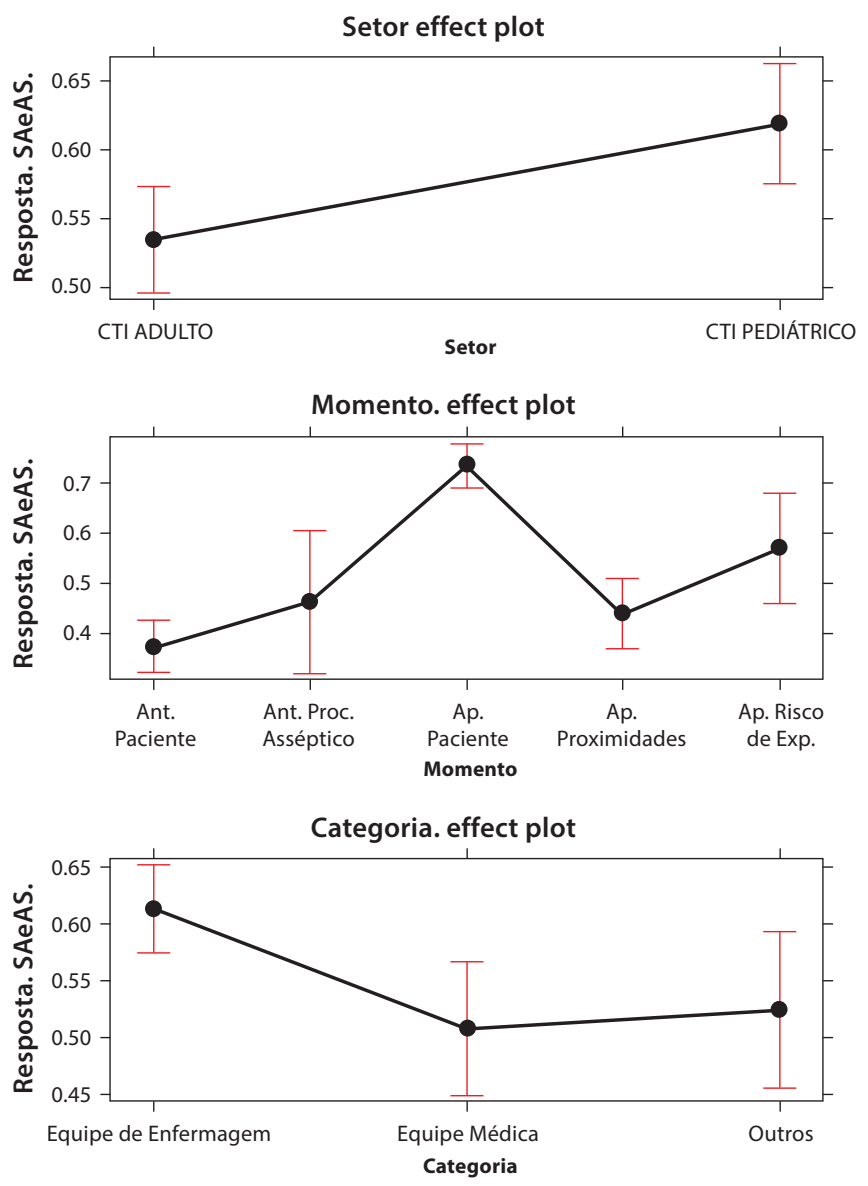

Figure 3 - Main effects of variables on water and soap and/or alcoholic solution use as a dependent variable (2016 and 2017)

\section{DISCUSSION}

\section{Educational actions carried out in 2016 and 2017}

Educational activities in 2016 were held in July and lasted 30 days. They started with the event entitled Hand Hygiene Day, with the formation of an itinerant table that circulated through the hospital's facilities. At this table, a box for "reading contaminated hands" was created in order to encourage the correct performance of $\mathrm{HH}$ and to recall the five critical moments for $\mathrm{HH}$. Moreover, demonstration was carried out on culture plates with unhygienized hands, hands sanitized with water and soap and hands sanitized with alcoholic solution. Culture plates aimed to materialize on the concrete plane about the effectiveness of $\mathrm{HH}$ with alcoholic solution use. It was associated with that moment, the clarification of any doubts and awareness of professionals about $\mathrm{HH}$, at the right time and in the right way, in the prevention of HAl. 
At the end of the Campaign, observations began in the sectors (Adult ICU and Pediatric ICU) of the institution. From the results of the analysis carried out in 2016, new guidelines were established for educational actions of the following year.

$\mathrm{HH}$ activities of the year were held in May and lasted 30 days. The following strategies were determined: 1) observation that the itinerant table influences the greater participation of professionals; 2) maintenance of the dynamics of the black box, as it was observed that many professionals were encouraged to participate in the Campaign out of curiosity; 3) maintenance of the poster provided by ANVISA about $\mathrm{HH}^{(10)}$. The posters provided explanatory information about the five moments of $\mathrm{HH}$; 4) a sector-based approach aimed at medical professionals based on analysis in the previous year. After the end of the activities, the observations based on the WHO guide began ${ }^{(8)}$.

Finally, the performance of a diagnostic evaluation, through the previous observation of the professionals' $\mathrm{HH}$ practices, is reported as essential in studies related to the theme, since it seeks to know the group's performance, thus enabling focused strategies ${ }^{(11)}$.

\section{Repercussions of educational actions (year 2016 and 2017)}

The analysis for 2016 and 2017 was concerned with the fact that dynamic activities aimed at raising the awareness of professionals about $\mathrm{HH}$ were carried out. According to the Guide to the Implementation of the WHO Multimodal Hand Hygiene Improvement Strategy, direct observational surveys should be carried out without the knowledge of the professionals in focus, as it is thus possible to obtain an assessment that avoids the hawthorne effect. This effect consists of a forced positive change in the behavior of a group of workers in relation to the objectives of a company/institution, management, direction or by some higher hierarchical sphere ${ }^{(12)}$. In the study, compliance was reported in terms of avoiding this effect.

There is a greater Odds Ratio of professionals to perform $\mathrm{HH}$ in Pediatric ICUs when compared to Adult ICUs. This result may be associated with a greater participation of Pediatric ICU professionals in hygiene and involvement campaigns of HICS professionals, continuing education, sectorial heads, and nursing residents. The involvement of these professionals may have been a decisive factor in the greater adherence to the practice of $\mathrm{HH}$ in Pediatric ICUs. Another aspect may be related to the pediatric environment. A study carried out with nursing professionals at a university hospital in southern Brazil showed that professionals working in this sector have a greater chance of developing and increasing strategies to improve care to children and their families ${ }^{(13)}$.

As for the population analysed, the nursing team obtained a higher Odds Ratio in performing $\mathrm{HH}$ and, in 2017, showed improvements in $\mathrm{HH}$ moments when compared to the other professional categories studied. However, these results are not satisfactory in view of the WHO's determinations regarding the treatment of patients with COVID-19, but demonstrate that educational actions, through Campaigns, had positive effects on the behavior of these professionals $s^{(4,14)}$.

In relation to $\mathrm{HH}$ moments, "after contact with the patient" had a greater chance of occurring in the professional teams evaluated. This result corroborates the culture of self-protection and is similar to the annual report made by Kingston General (Canada), carried out from April 2014 to March 2015. The study shows that the $\mathrm{HH}$ compliance rate was $79.5 \%$ in the indications "before" contact and 87.5\% "after" contact ${ }^{(15)}$.

$\mathrm{HH}$ is an essential component of infection prevention and control. However, this technique is generally neglected by health professionals in developed and developing countries, with compliance rates below $20 \%{ }^{(16)}$.

The opportunity of $\mathrm{HH}$ in the professional categories refers to the research carried out in a hospital in Porto Alegre, Brazil on $\mathrm{HH}$ actions by professionals, where the culture of using gloves as a "barrier" to $\mathrm{HH}$ was observed ${ }^{(17)}$. Evidence about glove use was described in the field diaries during the reports analysed in the present study.

The WHO points out that in the treatment of patients with COVID-19, glove use does not replace the need for $\mathrm{HH}$ and their respective action must be performed frequently ${ }^{(18)}$. Allied to $\mathrm{WHO}$ recommendations, ANVISA (equivalent to the US's FDA) reinforces that $\mathrm{HH}$ is recommended after the removal of personal protective equipment (PPE) in isolation areas or with suspected COVID-19(19).

A study carried out in an ICU in a hospital in the northern district of Sheung Shui/Hong Kong assessed the risks for health workers in the care of patients with COVID-19. This study reported that even using double gloves, there is a strong recommendation for $\mathrm{HH}$ by health professionals ${ }^{(20)}$.

Concerning the solution used, there is a variety of behavior regarding "alcoholic solution" and/or "water and soap" use. It is noteworthy that in the analysed reports, inadequate supply or absence of limitations of these elements in the studied settings was not reported.

Water and soap use was reported in studies carried out in countries with a tropical climate, where a predilection for $\mathrm{HH}$ with water and soap was noted, which directly refers to a greater sense of cleanliness of the hands ${ }^{(21)}$. The WHO document on rational use of PPE for COVID-19 recommends alcohol-based $\mathrm{HH}$ and, in case of dirt, water and soap use ${ }^{(18)}$.

Based on a diagnostic assessment that covered previous observations of the behavior of professionals in highly-complex sectors, strategic actions were determined about $\mathrm{HH}$, which would be worked on with professionals.

Evidence shows that educational actions have had positive effects, especially on nursing workers and should be developed with the aim of guidance and encouragement, in addition to building knowledge that covers biological and occupational risks in all aspects ${ }^{(11,22)}$.

\section{Study limitations}

Replication in other health institutions is suggested to verify if similar responses occurred, based on the strategy adopted in the present study.

\section{Contributions to nursing, health, and public policies}

In view of the contamination potential of Sars-CoV-2 and the high contamination of health professionals due to the culture of not $\mathrm{HH}$ at all times, studies that have an impact and measures to 
fight infection caused by COVID-19 emerge as factors of extreme importance by national public health institutions in Brazil and the world. Moreover, the aforementioned study follows the role of Brazil and the nursing area in advancing knowledge that requires prevention and health promotion actions.

\section{CONCLUSION}

Compliance with $\mathrm{HH}$ guidelines is one of the components in the combat of COVID-19 transmission in the hospital environment.

The nursing team was more associated with $\mathrm{HH}$ when compared to the other professional categories studied. In relation to the moments "after contact with the patient", it was the most common action, corroborating self-protection and the culture of using gloves as protective barriers, predisposing $\mathrm{HH}$ not to perform. As for the solution used for $\mathrm{HH}$, there was a similar behavior by professionals in the use of "alcoholic solution" and "water and soap".

From the comparison between the results of the years 2016 and 2017 , it is possible to direct continuous adherence strategies that can be effective in complying with $\mathrm{HH}$ among health professionals. In the study, strategic actions based on diagnostic situation of the environment, previous analysis of the behavior of health professionals and team involvement showed to be positive in Pediatric ICUs. The replication of actions based on such strategies can be considered in adhering to $\mathrm{HH}$ in highly complex sectors in view of the current outbreak of COVID-19. The strategies used in the Campaign demonstrate that the deficiency related to $\mathrm{HH}$ compliance does not occur exclusively due to the lack of knowledge of the $\mathrm{HH}$ technique and indications, but due to the devaluation of the safety culture.

In view of the current outbreak of COVID-19, the frequent exposure to the pathogen in sectors of high complexity predisposes professionals and patients to acquire or transmit the infection. The removal of PPE, which happens after contact with the patient, is also reported as one of the essential elements that prevent contamination of professionals. Therefore, actions aimed at reducing infection and protecting professionals, through simple and low-cost measures, should be considered.

\section{REFERENCES}

1. Chen X, Yu B. First two months of the 2019 Coronavirus Disease (COVID-19) epidemic in China: real-time surveillance and evaluation with a second derivative model. Glob Health Res Policy. 2020;5(1). doi: 10.1186/s41256-020-00137-4

2. Lai THT, Tang EWH, Fung KSC, Li KKW. Does hand hygiene reduce SARS-CoV-2 transmission? Graefe's Arch Clin Exp Ophthalmol. 2020;1. doi: $10.1007 / \mathrm{s} 00417-020-04652-5$

3. Ong SWX, Tan YK, Chia PY, Lee TH, Ng OT, Wong MSY, et al. Air, Surface Environmental, and Personal Protective Equipment Contamination by Severe Acute Respiratory Syndrome Coronavirus 2 (SARS-CoV-2) from a Symptomatic Patient. JAMA. 2020. Available from: doi:10.1001/ jama.2020.3227

4. Organização Panamerica de Saúde. OPAS/OMS Brasil - Folha informativa - COVID-19 (doença causada pelo novo coronavírus) [Internet]. 2020 [cited 2020 Apr 8]. p. 2. Available from: https://www.paho.org/bra/index.php?option=com_content\&view=article\&id=6101:covid19\&ltemid=875

5. Kratzel A, Todt D, V'kovski P, Steiner S, Gultom ML, Thao TTN, et al. Efficient inactivation of SARS-CoV-2 by WHO-recommended hand rub formulations and alcohols. bioRxiv [Internet]. 2020 Mar 17 [cited 2020 Apr 8];2020.03.10.986711. Available from: http://biorxiv.org/content/ early/2020/03/17/2020.03.10.986711.abstract

6. Chou DTS, Achan P, Ramachandran M. The World Health Organization " 5 Moments of Hand Hygiene": the scientific foundation. J Bone Jt Surg - Br Vol. 2012;94-B(4):441-5.

7. Organização Mundial da Saúde. Agência Nacional de Vigilância Sanitária. Diretrizes da oms sobre higienização das mãos na assistência à saúde. 2016;41(0). Available from: https://www20.anvisa.gov.br/segurancadopaciente/index.php/publicacoes/item/ diretrize-as-omshigienizacaomaos-versaoprelim-avancada

8. Ministério da Saúde. Anvisa, Fiocruz. Anexo 01: Protocolo para a prática de higiene das mãos em serviços de saúde. 2013;16. Available from: http://www.hospitalsantalucinda.com.br/downloads/prot_higiene_das_maos.pdf

9. Monteiro MN, Cavalcanti C, Ostermann F. Análise de Correspondência aplicada à pesquisa em Ensino de Ciências - Resultats de la cerca Dipòsit Digital de Documents de la UAB. Univ Autónoma Barcelona [Internet]. 2017 [cited 2020 Apr 8];1319-24. Available from: https://ddd. uab.cat/search?f=title\&p=Análise de Correspondência aplicada à pesquisa em Ensino de Ciências\&sc=1\&ln=ca

10. Ministério da Saúde (BR). Agência Nacional de Vigilância Sanitária. Cartaz 7 - Práticas seguras de higiene das mãos para prevenção de infecções relacionadas à assistência à saúde [Internet]. ANVISA. 2017 [cited 2020 Apr 20]. Available from: https://www20.anvisa.gov.br/ segurancadopaciente/index.php/publicacoes/item/cartaz-7

11. Paula DG, Pinto FF, Silva RFA, Paula VG. Estratégias de adesão à higienização das mãos por profissionais de saúde. Rev Epidemiol Control Infecção. 2017;7. doi: 10.17058/reci.v7i2.7731

12. Alvim ALS. Higienização das mãos: como reduzir o efeito Hawthorne? Assoc Min Epidemiol e Control Infecções [Internet]. 2017[cited 2020 Apr 8];3. Available from: https://ameci.org.br/wp-content/uploads/2017/04/Higieniza\%C3\%A7\%C3\%A3o-das-m\%C3\%A3os-como-reduziro-efeito-Hawthorne.pdf

13. Ribeiro JP, Gomes GC, Thofehrn MB, Porto AR, Rodrigues LPV. Ambiente de pediatria: aspectos que auxiliam no processo de trabalho e na produção de saúde. Rev Enferm UFPE[Internet]. 2017 [cited 2020 Apr 29];11(12):5275. Available from: https://periodicos.ufpe.br/revistas/ revistaenfermagem/article/view/22786 
14. World Health Organization-WHO. Rational use of personal protective equipment for coronavirus disease (COVID-19): interim guidance [Internet]. Genebre; 2020 [cited 2020 Apr 13]. Available from: https://apps.who.int/iris/bitstream/handle/10665/331215/WHO-2019-nCovIPCPPE_use-2020.1-eng.pdf

15. Patient Safety Indicator Reports. KHSC Kingston Health Sciences Centre [Internet]. [cited 2020 Apr 8]. Available from: https://kingstonhsc.ca/ about-kgh/achieving-our-aim/quality-and-patient-safety/patient-safety-indicator-reports

16. Lotfinejad N, Peters A, Pittet D. Hand hygiene and the novel coronavirus pandemic: the role of healthcare workers. J Hosp Infect. 2020; S0195-6701(20)30116-X. doi: 10.1016/j.jhin.2020.03.017

17. Souza LM, Ramos MF, Becker ESS, Meirelles LCS, Monteiro SAO. Adherence to the five moments for hand hygiene among intensive care professionals. Rev Gaucha Enferm. 2015;36(4):21-8. doi: 10.1590/1983-1447.2015.04.49090

18. Feng S, Shen C, Xia N, Song W, Fan M, Cowling BJ. Rational use of face masks in the COVID-19 pandemic. Lancet Respir Med. 2020;8(5):434-6. doi: 10.1016/S2213-2600(20)30134-X

19. Agência Nacional de Vigilância Sanitária. Gerência de Vigilância e Monitoramento em Serviços de Saúde, Gerência Geral de Tecnologia em Serviços de Saúde, Orientações para serviços de saúde: medidas de prevenção e controle que devem ser adotadas durante a assistência aos casos suspeitos ou confirmados de infecção pelo novo coronavírus (SARS-CoV-2). [Internet]. Brasília; 2020[cited 2020 Apr 29]. Available from: http://portal.anvisa.gov.br/documents/33852/271858/Nota+Técnica+n+04-2020+GVIMS-GGTES-ANVISA/ ab598660-3de4-4f14-8e6f-b9341c196b28

20. Cheung JCH, Ho LT, Cheng JV, Cham EYK, Lam KN. Staff safety during emergency airway management for COVID-19 in Hong Kong. Vol. 8, The Lancet Respiratory Medicine. Lancet Publishing Group; 2020. p. e19.

21. Paula AO, Oliveira AC. Healthcare workers perception regarding hand hygiene. Rev Pesqui Cuid Fundam [Internet]. 2017 [cited 2020 Apr 8];9(2):321. Available from: https://www.ssoar.info/ssoar/handle/document/53437

22. Silva BR, Carreiro MA, Simões BFT, Paula DG. Monitoring hand hygiene adherence in an intensive care unit. Rev Enferm [Internet]. 2018 Aug 25 [cited 2020 Apr 8];26(0):33087. Available from: https://www.e-publicacoes.uerj.br/index.php/enfermagemuerj/article/view/33087/26143 